\title{
Disposition of Cefquinome in Turkeys (Meleagris gallopavo) Following Intravenous and Intramuscular Administration
}

\author{
Mohamed Elbadawy $1, * \mathbb{C}$, Ahmed Soliman ${ }^{2}\left(\mathbb{D}\right.$, Amira Abugomaa $\left.{ }^{3, *} \mathbb{(}\right)$, Adel Alkhedaide ${ }^{4}$, \\ Mohamed Mohamed Soliman ${ }^{4}$ (D) and Mohamed Aboubakr ${ }^{1}$ (D) \\ 1 Department of Pharmacology, Faculty of Veterinary Medicine, Benha University, Moshtohor, \\ Toukh 13736, Qalioubiya, Egypt; mohamed.aboubakr@fvtm.bu.edu.eg \\ 2 Pharmacology Department, Faculty of Veterinary Medicine, Cairo University, Giza 12211, Egypt; \\ galalpharma@cu.edu.eg \\ 3 Faculty of Veterinary Medicine, Mansoura University, Mansoura 35516, Dakahliya, Egypt \\ 4 Clinical Laboratory Sciences Department, Turabah University College, Taif University, \\ Taif 21995, Saudi Arabia; a.khedaide@tu.edu.sa (A.A.); mmsoliman@tu.edu.sa (M.M.S.) \\ * Correspondence: mohamed.elbadawy@fvtm.bu.edu.eg (M.E.); s193249s@st.go.tuat.ac.jp (A.A.); \\ Tel.: +81-90-2076-8122 (M.E.); +81-90-1238-1298 (A.A.)
}

check for updates

Citation: Elbadawy, M.; Soliman, A.; Abugomaa, A.; Alkhedaide, A.; Soliman, M.M.; Aboubakr, M. Disposition of Cefquinome in Turkeys (Meleagris gallopavo) Following Intravenous and Intramuscular Administration. Pharmaceutics 2021, 13, 1804. https://doi.org/10.3390/ pharmaceutics13111804

Academic Editor: Elisa Escudero

Received: 18 September 2021

Accepted: 24 October 2021

Published: 28 October 2021

Publisher's Note: MDPI stays neutral with regard to jurisdictional claims in published maps and institutional affiliations.

Copyright: (C) 2021 by the authors. Licensee MDPI, Basel, Switzerland. This article is an open access article distributed under the terms and conditions of the Creative Commons Attribution (CC BY) license (https:// creativecommons.org/licenses/by/ $4.0 /)$.

\begin{abstract}
The bioavailability and pharmacokinetics in turkeys of cefquinome (CFQ), a broadspectrum 4th-generation cephalosporin antibiotic, were explored after a single injection of $2 \mathrm{mg} / \mathrm{kg}$ body weight by intravenous (IV) and intramuscular (IM) routes. In a crossover design and 3-weeks washout interval, seven turkeys were assigned for this objective. Blood samples were collected prior to and at various time intervals following each administration. The concentration of CFQ in plasma was measured using HPLC with a UV detector set at $266 \mathrm{~nm}$. For pharmacokinetic analysis, non-compartmental methods have been applied. Following IV administration, the elimination halflife $\left(\mathrm{t}_{1 / 2 \mathrm{z}}\right)$, distribution volume at steady state $\left(\mathrm{Vd}_{\mathrm{ss}}\right)$, and total body clearance $\left(\mathrm{Cl}_{\text {tot }}\right)$ of CFQ were $1.55 \mathrm{~h}, 0.54 \mathrm{~L} / \mathrm{kg}$, and $0.32 \mathrm{~L} / \mathrm{h} / \mathrm{kg}$, respectively. Following the IM administration, CFQ was speedily absorbed with an absorption half-life $\left(\mathrm{t}_{1 / 2 \mathrm{ab}}\right)$ of $0.25 \mathrm{~h}$, a maximum plasma concentration $\left(\mathrm{C}_{\max }\right)$ of $2.71 \mu \mathrm{g} / \mathrm{mL}$, attained $\left(\mathrm{T}_{\max }\right)$ at $0.56 \mathrm{~h}$. The bioavailability $(\mathrm{F})$ and in vitro plasma protein binding of CFQ were $95.56 \%$ and $11.5 \%$, respectively. Results indicated that CFQ was speedily absorbed with a considerable bioavailability after IM administration. In conclusion, CFQ has a favorable disposition in turkeys that can guide to estimate optimum dosage regimes and eventually lead to its usage to eradicate turkey's susceptible bacterial infections.
\end{abstract}

Keywords: cefquinome; bioavailability; HPLC; pharmacokinetics; poultry; turkeys

\section{Introduction}

Pathogenic bacteria constitute a menace to the health of humans and animals and lead to a significant economic burden; thus, an antibacterial intervention is a vital consideration [1]. However, the emergence of bacterial resistance to antibacterials is a constant medical issue due to the regular and hazardous use of classical antibiotics. This problem can partly be solved by the usage of appropriate and effective antibacterial drugs.

In veterinary practice, cephalosporins are very often prescribed for the remediation of bacterial infections [2,3]. Their mode of action is attributed to the disruption of the peptidoglycan layer which is important for the structural integrity of the bacterial cell wall resulting in lysis and death of the bacterial cell [2]. Cefquinome (CFQ) is a broad-spectrum parenteral bactericidal cephalosporin (4th-generation) antibiotic. It was developed specifically for veterinary usage [4]. The unique structural design of CFQ (Figure 1) was obtained by setting a methoxyimino-aminothiazolyl moiety into cephalosporin's acyl side chain and a quaternary quinoline group at position 3 of the cephem ring resulting in the zwitterionic structure of CFQ. This unique design notably boosts the antibacterial efficacy, spectrum, 
and stability of CFQ against $\beta$-lactamases-producing and methicillin-resistant bacteria as Enterococci and Staphylococci [5-7]. Further, the zwitterionic structure facilitates its rapid permeation beyond biological membranes and through the porins of bacterial cell walls, ensuring its speedy effect following injection [8]. These special structure grants preferable pharmacokinetic properties to CFQ such as speedy absorption, high bioavailability, primary elimination in an unchanged form via the kidneys, and low protein binding [9]. The spectrum of CFQ includes different bacterial strains such as Streptococci, Staphylococci, Enterobacteriaceae family (E. coli, Salmonella, Klebsiella, Citrobacter species), and Pseudomonas aeruginosa [10-12]. Therefore, it is prescribed for the remediation of bacterial diseases of the respiratory system in equines and poultry, as well as acute mastitis, mastitis-metritisagalactia syndrome, and foot rot disease in bovines $[2,10,13,14]$.<smiles>CO/N=C(\C(=O)N[C@@H]1C(=O)N2C(C(=O)O)=C(C[n+]3cccc4c3CCCC4)CS[C@H]12)c1csc(N)n1</smiles>

Figure 1. Chemical structure of cefquinome.

Extensive pharmacokinetic studies have been performed for CFQ in numerous mammals under normal and different physiological experimental conditions such as foals [14], ponies [15], horses [16], pigs [17], piglets [18-20], dogs [21,22], calves, [23,24], cattle [25,26], sheep $[27,28]$, goats $[29,30]$, rabbits [31,32] and mice [33,34]. The CFQ pharmacokinetics have been also determined in fishes including tilapia [35], carp [36], and salmon [37]. These investigations established a conceptual framework for the reasonable and clinical usage of CFQ in these species. A limited amount of research has been conducted to determine the pharmacokinetics of CFQ in avian species such as ducks [9], chickens [38], ducklings and goslings [39], black swans (Cygnus atratus) [11], and laying hens [40]. The data of these studies revealed differences among these avian species in CFQ disposition, entailing precise assessment before its clinical usage in new avian species. Usage of allometric scaling for dose extrapolation among avian species could lead to inaccuracies, especially when drugs are prone to metabolic alterations [41,42].

The kinetics of CFQ has not been studied in turkeys yet. Therefore, the current study aimed to determine the CFQ's disposition profile in turkeys following a single intravenous (IV), and intramuscular (IM) administration to get information for the future establishment of optimal dosage regimens.

\section{Materials and Methods}

\subsection{Reagents and Chemicals}

Cefquinome sulfate powder of $84.1 \%$ purity was purchased from Hebei Yuanzheng Pharmaceutical Co., Ltd. (Hebei, China). The injectable solutions of CFQ were prepared by dissolving CFQ powder in sterilized distilled water. An HPLC grade CFQ standard (95\% purity) was purchased from Fujifilm Wako Pure Chemical Co. (Osaka, Japan), and used for validation of the calibration method. The purity percentage of CFQ sulfate powder (84.1\%) and CFQ standard (95\%) was considered when preparing the administered doses and the solutions of CFQ standard. Other reagents and chemicals used in the present study were of analytical reagent grade. 


\subsection{Experimental Birds}

Seven male turkeys, 15 weeks of age, 6-7 kg body weight (BW), were purchased from a local commercial turkey farm. The turkeys were maintained at $20{ }^{\circ} \mathrm{C}, 65 \%$ relative humidity, and a $12 \mathrm{~h} /$ day light cycle. There were two weeks of acclimatization before experimentation to ensure that their bodies are free from any residual drugs such as antibacterials and anticoccidials. Standard commercial pelleted feed, free from antibiotics and coccidiostats, and water were supplied ad libitum. The health status of turkeys was daily assessed, and no signs of disease were seen. The experimental protocol was developed following the directions of the Declaration of Helsinki and accepted by the Ethical Committee of the Faculty of Veterinary Medicine, Benha University, Egypt (Number: BUFVTM 02-07-21). All efforts were exerted to maintain comfort and minimize pain to turkeys.

\subsection{Experimental Design}

The doses were calculated precisely based on the purity percentage of CFQ sulfate powder $(84.1 \%)$ and the individual BW of each turkey prior to CFQ injection. A crossover design [43] was used where the washout interval was three weeks (Figure 2). The turkeys were given a single dose of $2 \mathrm{mg} / \mathrm{kg}$ BW of CFQ either IV into the left brachial vein or IM into the thigh muscles. The selected dose in the current study was based on the doses that were mostly used in avian species, chicken, duck, and geese [9,38-40]. Blood samples $(1.5 \mathrm{~mL})$ from each turkey were gathered from the right brachial vein into tubes containing heparin just before medication (time $=0$ ) and then at $0.08,0.16,0.25,0.5,1,2,4,6,8$, and $12 \mathrm{~h}$ after CFQ injection. After centrifugation of these blood samples for $10 \mathrm{~min}$ at $1600 \times \mathrm{g}$, plasma samples were separated into $1.5 \mathrm{~mL}$ tubes, labeled appropriately, and stored at $-30{ }^{\circ} \mathrm{C}$ until it was assayed by HPLC system.

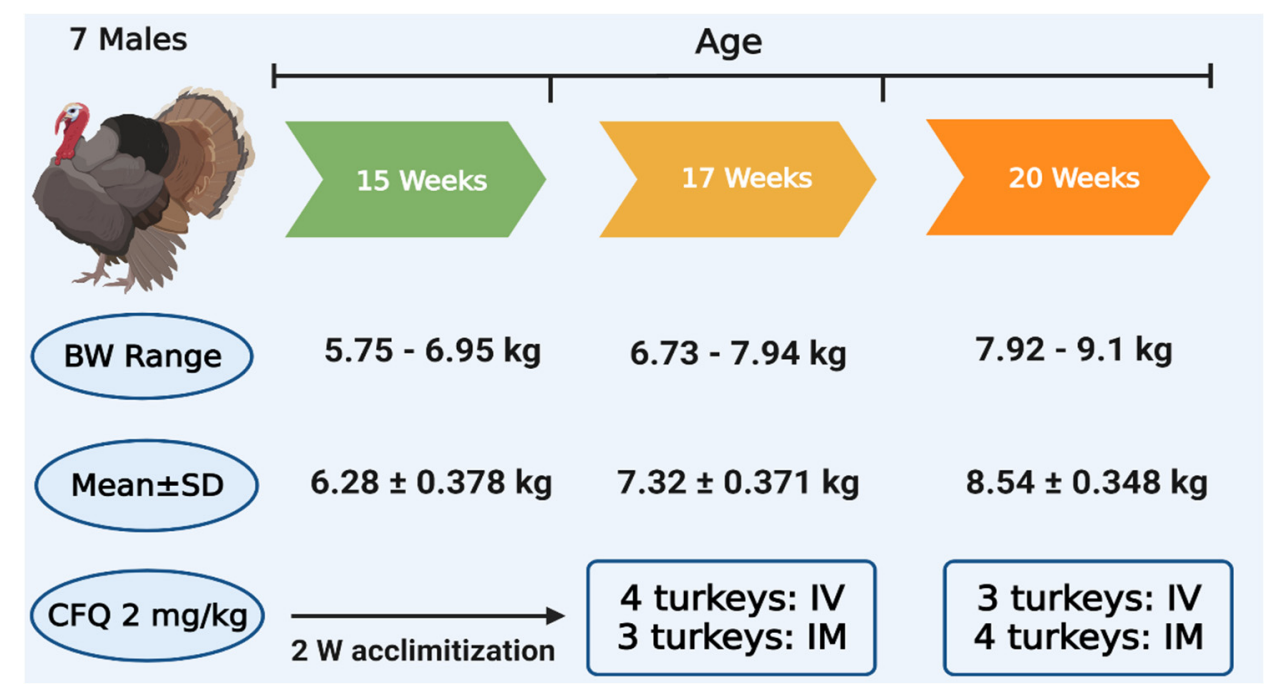

Figure 2. Body weights and experimental design for injection of CFQ to turkeys.

\subsection{Analytical Method}

The concentration of CFQ in turkey's plasma was analyzed by HPLC as determined previously [9]. Briefly, $300 \mu \mathrm{L}$ each plasma sample was deproteinized using $600 \mu \mathrm{L}$ of methanol, vortexed for $10 \mathrm{~s}$ and centrifuged at $20,000 \times \mathrm{g}$ for $15 \mathrm{~min}$ in a cooling centrifuge at $4{ }^{\circ} \mathrm{C}$. Thereafter, the supernatant of each sample was gathered, dried with nitrogen gas, reconstituted in $300 \mu \mathrm{L}$ of mobile phase, and filtered through a $0.45-\mu \mathrm{m}$ HPLC filter (Chromatodisc ${ }^{\circledR}, 4 \mathrm{P}$, Kurabo Biomedical Industries, Ltd., Osaka, Japan). The HPLC system (HP-1100 HPLC system, Agilent Technologies, Palo Alto, CA, USA) used in the present study was equipped with a degasser, a quaternary pump, an autosampler, a UV detector, and a column heater. The mobile phase was composed of sodium perchlorate $(85 \mathrm{mM}$ 
(9.16 gm/L))-triethylamine (4.6 $\mathrm{mL}$, to dissolve sodium perchlorate)-phosphate (to set $\mathrm{pH}$ at 3.6)-buffer and acetonitrile $(88: 12, v / v)$. The flow rate was put at one $\mathrm{mL} / \mathrm{min}$. The analytical separation of CFQ was done by a reverse phase C18 Hypersil-BDS column $\left(250 \times 4.6 \mathrm{~mm}, 5 \mu \mathrm{m}\right.$, Agilent Technologies) with the temperature maintained at $30{ }^{\circ} \mathrm{C}$, a $\mathrm{UV}$ wavelength set at $266 \mathrm{~nm}$, and the injection volume was $20 \mu \mathrm{L}$.

\subsection{Method Validation}

The stock solution of CFQ (equivalent to $1 \mathrm{mg} / \mathrm{mL}$ ) was prepared by dissolving $10.53 \mathrm{mg}$ of CFQ standard (95\%) in $10 \mathrm{~mL}$ of the mobile phase. The working solutions of the CFQ standard $(0.01,0.05,0.1,1,2.5$, and $5 \mu \mathrm{g} / \mathrm{mL})$ by diluting the CFQ stock solution with mobile phase. Calibration was performed by spiking $60 \mu \mathrm{L}$ of each standard working solution to $240 \mu \mathrm{L}$ of blank turkey's plasma and assayed as described above. The means of five values were applied to plot standard curves (peak area vs. CFQ concentration). The recovery rate from plasma, inter-day and intra-day coefficients of variability were determined via repetitive analysis of plasma samples. The average plasma recovery rate of CFQ was high (94\%). The values of intra- and inter-day coefficients of variability were ranged from $4.07 \sim 4.63 \%$ and $4.91 \sim 5.35 \%$, respectively ( $n=5$, three times, three days). The lower limits of detection (LOD) and quantification (LOQ) were determined using the signal-to-noise method and were 0.010 and $0.035 \mu \mathrm{g} / \mathrm{mL}$, respectively. The peak of CFQ in plasma has appeared on a chromatogram at $12 \mathrm{~min}$ (Supplementary Figure S1).

\subsection{Plasma Protein Binding Extent of $C F Q$}

The extent of CFQ binding to plasma protein was assessed in vitro using the ultrafiltration method [44]. The various CFQ standard concentrations (equivalent to 0.2, 2, 20 and $100 \mu \mathrm{g} / \mathrm{mL}$ were prepared in deionized water by diluting the stock solution of CFQ (equivalent to $1 \mathrm{mg} / \mathrm{mL}$ deionized water). Thereafter, $50 \mu \mathrm{L}$ of each standard working solution was mixed in triplicate with $950 \mu \mathrm{L}$ of fresh blank turkeys' plasma to yield plasma samples spiked with known CFQ concentrations of $0.01,0.1,1$, and $5 \mu \mathrm{g} / \mathrm{mL}$. After vortexing for $20 \mathrm{~s}$, the spiked samples were maintained for $30 \mathrm{~min}$ at $37^{\circ} \mathrm{C}$ to permit binding of CFQ with plasma proteins of plasma samples. Subsequently, one $\mathrm{mL}$ of each spiked sample was dropped into the reservoir of Ultrafree ${ }^{\circledR}$ centrifugal filter tube (pore diameter of $0.45 \mu \mathrm{m}$, Millipore Corporation, Tokyo, Japan). The ultrafiltration was conducted by centrifugation of the Ultrafree ${ }^{\circledR}$ centrifugal filter tubes at $2500 \times g$, at $37^{\circ} \mathrm{C}$ for up to 30 min until the required amount of the ultrafiltrate was achieved. In the obtained ultrafiltrate, CFQ concentrations were assayed as mentioned above. The percentage of CFQ plasma protein binding was assessed regarding the initial sample concentration using the following Equation (1):

$$
\text { Plasma protein binding }(\%)=100-\left[\left\{\frac{\text { concentration } / \mathrm{mL} \text { ultrafiltrate }}{\text { initial concentration } / \mathrm{mL} \text { plasma }}\right\} \times 100\right]
$$

\subsection{Pharmacokinetic Analysis}

After IV and IM administrations and HPLC analysis of plasma samples, the calculated plasma concentrations of CFQ for each turkey at each sampling time were presented as mean \pm standard deviation (SD) values (Supplementary Table S1). The non-compartmental analysis method [45] was applied to calculate several pharmacokinetic parameters using the concentration vs. time data of CFQ in each turkey following the IV and IM administrations and the WinNonlin program (version 6.1, Pharsight, Mountain View, CA, USA). The calculated parameters include total body clearance $\left(\mathrm{Cl}_{\mathrm{tot}}\right)$, distribution volume at steady state $\left(\mathrm{Vd}_{\mathrm{ss}}\right)$, and mean residence time (MRT). The trapezoidal method was applied to calculate the area under the concentration-time curve (AUC), the area under the first moment curve (AUMC). Mean residence time (MRT) was calculated as MRT $=\mathrm{AUMC} / \mathrm{AUC}$ and the total body clearance $\left(\mathrm{Cl}_{\text {tot }}\right)$ as $\mathrm{Cl}_{\text {tot }}=$ Dose $/ \mathrm{AUC}$. The elimination rate constant $(\mathrm{z})$ was calculated by linear regression of several points (4-6) on the terminal phase of logarith- 
mic plasma concentrations vs. time curve. The terminal half-lives $\left(t \frac{1}{2} \mathrm{z}\right)$ were calculated using where $t_{\frac{1}{2} \mathrm{z}}=0.693 / \mathrm{z}$. The peak plasma level $\left(C_{\max }\right)$ and time to $C_{\max }\left(T_{\max }\right)$ after IM administration of CFQ were determined using the curve of plasma concentration vs. time for each turkey. The absolute bioavailability (F) of CFQ after IM was calculated as $\mathrm{F}=\mathrm{AUC}_{\mathrm{IM}} / \mathrm{AUC}_{\mathrm{IV}} \times 100$. The half-life of absorption of CFQ after IM administration was determined using the equation: $\mathrm{t}_{1 / 2 \mathrm{ka}}=0.693 \times$ mean absorption time (MAT). All obtained values are expressed as Mean $\pm \mathrm{SD}$.

\section{Results}

No abnormalities such as irritation, pain signs, or lameness were noticed in turkeys following the administrations of CFQ. The semi-logarithmic plasma concentration vs. time curves of CFQ after the single IV and IM administration of $2 \mathrm{mg} / \mathrm{kg}$ BW are illustrated in Figure 3 and the mean \pm SD of pharmacokinetic parameter values are shown in Table 1.

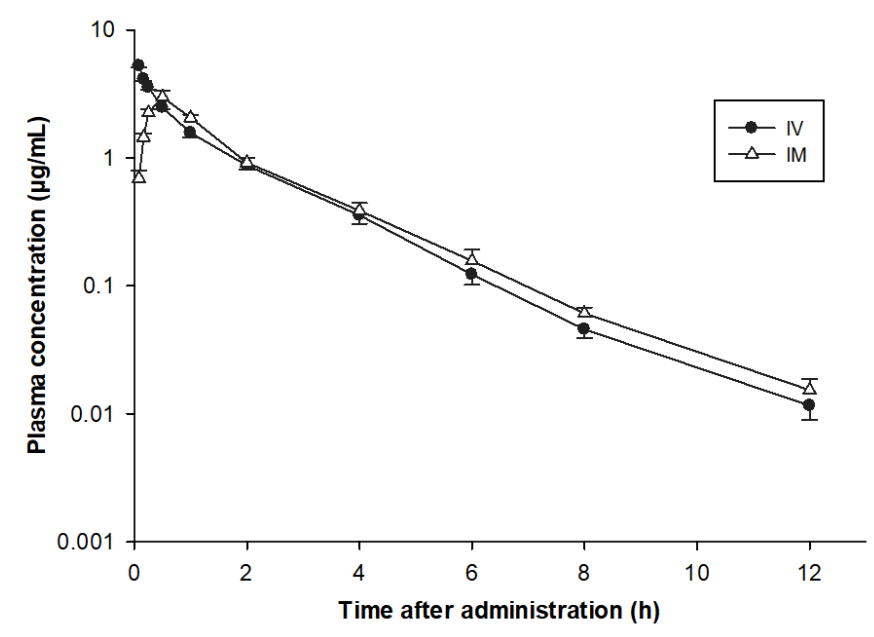

Figure 3. Semi-logarithmic graph depicting the time-concentration of cefquinome in plasma of turkeys after a single intravenous (IV) $(\bullet)$ and intramuscular $(\mathrm{IM})(\triangle)$ administration of $2 \mathrm{mg} / \mathrm{kg}$ $\mathrm{BW}(n=7)$.

Table 1. Plasma pharmacokinetic parameters of cefquinome in turkeys following intravenous (IV) and intramuscular (IM) administration of $2 \mathrm{mg} / \mathrm{kg}$ BW $(n=7)$. All values are expressed as Mean \pm SD.

\begin{tabular}{cccc}
\hline Parameters & Unit & IV & IM \\
\hline $\mathrm{C}^{0}$ & $\mu \mathrm{g} / \mathrm{mL}$ & $6.63 \pm 0.302$ & - \\
$\mathrm{t}_{1 / 2 \mathrm{ab}}$ & $\mathrm{h}$ & - & $0.253 \pm 0.0580$ \\
$\mathrm{t}_{1 / 2 \mathrm{z}}$ & $\mathrm{h}$ & $1.56 \pm 0.0631$ & $1.71 \pm 0.076$ \\
$\mathrm{AUC}_{0-\infty}$ & $\mu \mathrm{g} \cdot \mathrm{h} / \mathrm{mL}$ & $6.22 \pm 0.428$ & $5.94 \pm 0.443$ \\
$\mathrm{AUMC} \mathrm{C}_{0-\infty}$ & $\mu \mathrm{g} \cdot \mathrm{h} / \mathrm{mL}$ & $10.6 \pm 1.23$ & $12.3 \pm 1.52$ \\
$\mathrm{MRT}$ & $\mathrm{h}$ & $1.70 \pm 0.082$ & $2.07 \pm 0.117$ \\
$\mathrm{MAT}$ & $\mathrm{h}$ & - & $0.374 \pm 0.062$ \\
$\mathrm{Vd}$ & $\mathrm{L} / \mathrm{kg}$ & $0.547 \pm 0.0133$ & - \\
$\mathrm{Cl}_{\mathrm{tot}}$ & $\mathrm{L} / \mathrm{kg} / \mathrm{h}$ & $0.323 \pm 0.0255$ & - \\
$\mathrm{C}_{\max }$ & $\mu \mathrm{g} / \mathrm{mL}$ & - & $2.71 \pm 0.161$ \\
$\mathrm{~T}_{\max }$ & $\mathrm{h}$ & - & $0.558 \pm 0.018$ \\
$\mathrm{~F}$ & $\%$ & - & $95.6 \pm 1.78$
\end{tabular}

$\mathrm{C}^{0}$; concentration at zero time (immediately after single IV injection), $\mathrm{t}_{1 / 2 \mathrm{ab}}$; absorption half-life after IM administration, $\mathrm{t}_{1 / 2 \mathrm{z}}$; terminal elimination half-life, $\mathrm{AUC}_{0-\infty}$; area under plasma concentration-time curve from zero time to infinity, $\mathrm{AUMC}_{0-\infty}$; area under moment curve from zero time to infinity, MRT; mean residence time, MAT; mean absorption time, $\mathrm{Vd}_{\mathrm{ss}}$; volume of distribution at steady-state, $\mathrm{Cl}_{\text {tot }}$; total body clearance. $\mathrm{C}_{\max }$; maximum plasma concentration, $\mathrm{T}_{\max }$; time to peak plasma concentration, $\mathrm{F}$; absolute bioavailability. 
The individual pharmacokinetic parameters are presented in Supplementary Table S2. Following IV administration, CFQ concentrations declined from $5.25 \pm 0.0613 \mu \mathrm{g} / \mathrm{mL}$ at $0.083 \mathrm{~h}$ to $0.012 \pm 0.001 \mu \mathrm{g} / \mathrm{mL}$ at $12 \mathrm{~h}$ post-administration (Table 1). The half-life interval of elimination $\left(\mathrm{t}_{1 / 2 \mathrm{z}}\right), \mathrm{Vd}_{\mathrm{ss}}$, and $\mathrm{Cl}_{\text {tot }}$ of $\mathrm{CFQ}$ were $1.56 \pm 0.0631 \mathrm{~h}, 0.547 \pm 0.0133 \mathrm{~L} / \mathrm{kg}$, and $0.323 \pm 0.0255 \mathrm{~L} / \mathrm{h} / \mathrm{kg}$, respectively.

After IM administration, CFQ was speedily absorbed and detectable in plasma at 5 min of administration with a half-life of absorption $\left(t_{1 / 2 a b}\right)$ of $0.253 \pm 0.022 \mathrm{~h}$, a peak plasma level $\left(\mathrm{C}_{\max }\right)$ of $2.71 \pm 0.061 \mu \mathrm{g} / \mathrm{mL}$ and attained $\left(\mathrm{T}_{\max }\right)$ at $0.558 \pm 0.007 \mathrm{~h}$. The bioavailability (F) of CFQ was $95.6 \pm 0.676 \%$. No CFQ was detected in any turkey's plasma $24 \mathrm{~h}$ after IV or IM administration. The in vitro protein binding extent of CFQ spiked at concentrations of 0.01 to $5 \mu \mathrm{g} / \mathrm{mL}$ ranged from $10 \%$ to $13 \%$. The mean protein binding percentage at different drug concentrations was $11.6 \%$ (Table 2).

Table 2. In vitro plasma protein binding percentage of cefquinome in turkey plasma $(n=3)$.

\begin{tabular}{ccc}
\hline $\begin{array}{c}\text { Fortified CFQ Concentrations }(\mu \mathrm{g} / \mathrm{mL}) \\
\text { in Blank Plasma }\end{array}$ & Protein Binding \% & SD \\
\hline 0.01 & 13.01 & 1.78 \\
0.1 & 11.9 & 0.853 \\
1 & 11.3 & 1.48 \\
5 & 10.1 & 1.12 \\
Mean & 11.5 & 1.31 \\
\hline
\end{tabular}

\section{Discussion}

Analyzing the absorption, distribution, metabolism, and excretion (ADME) profile of drugs is the chief goal of pharmacokinetic studies. A drug's pharmacokinetic profile following a single injection may be well represented by $C_{\max }, T_{\max }, t_{1 / 2 z}$, and AUC evaluation [46]. Differences among avian species in the disposition of CFQ were shown in laying hens [40], healthy ducks [9], ducklings and gosling [39], healthy chickens [38], and black swans [11], necessitating thorough pre-clinical evaluation before administration to new species as turkeys.

As far as we know, the present research is the first to check the pharmacokinetic profile of CFQ in turkeys. We checked the disposition profile of CFQ in healthy turkeys after administration of $2 \mathrm{mg} / \mathrm{kg}$ BW via the IV and IM routes to obtain data for the future establishment of appropriate dosage regimens. The obtained data revealed that CFQ has rapid and almost complete absorption and satisfactory elimination rate that allows reasonable dosing intervals in turkey. Further, there were no noticed tissue irritation, lameness, or pain symptoms. Similarly, there were no adverse events following the administration of CFQ to several avian species such as ducklings and goslings [39], black swans (Cygnus atratus) [11], laying hens [40], healthy chickens [38], and mammals such as goats [47], buffalo calves [23] and horses [16]. These data from different species elucidate the safety of CFQ.

In the current study, we compared the obtained CFQ pharmacokinetic data in turkeys with those of CFQ in other avian species and mammals (Table 3). Our data revealed that after IV administration, CFQ was eliminated speedily from the turkey's plasma with $\mathrm{a} \mathrm{t}_{1 / 2 \mathrm{z}}$ of $1.56 \mathrm{~h}$. These data is quite identical to that reported for CFQ in ducks (1.57 h [9]) and black swans (Cygnus atratus, $1.69 \mathrm{~h} \mathrm{[11]),} \mathrm{longer} \mathrm{than} \mathrm{that} \mathrm{of} \mathrm{CFQ} \mathrm{in} \mathrm{chickens}$ (1.29 $\mathrm{h}$ [38]), ducklings (0.97 $\mathrm{h} \mathrm{[39]),} \mathrm{and} \mathrm{shorter} \mathrm{than} \mathrm{that} \mathrm{of} \mathrm{CFQ} \mathrm{in} \mathrm{gosling} \mathrm{(1.73} \mathrm{h} \mathrm{[39]).}$ In mammals, CFQ showed also speedy elimination after IV administration. The $t_{1 / 2 z}$ of CFQ were $2.32 \mathrm{~h}$ in horses [16], $2.1 \mathrm{~h}$ in cattle [26], $1.85 \mathrm{~h}$ in premature calves [24], 0.72 and $0.93 \mathrm{~h}$ in rabbits [31] and [32], $0.98 \mathrm{~h}$ beagle dogs [22] and $0.78 \mathrm{~h}$ in sheep [27]. In foals and mares, the $t_{1 / 2 z}$ of CFQ after IV administration of $1 \mathrm{mg} / \mathrm{kg}$ was 1.82 and $2.33 \mathrm{~h}$, respectively [15]. These data indicate the rapid elimination of CFQ after IV administration in turkeys, other avian species, and most mammals. However, in fish species, the $t_{1 / 2 z}$ of CFQ was substantially longer after intraperitoneal administration of $10 \mathrm{mg} / \mathrm{kg}$ BW. The $\mathrm{t}_{1 / 2 \mathrm{z}}$ of CFQ was $6.88 \mathrm{~h}$ in crucian carp (Carassius auratus gibelio) at $25^{\circ} \mathrm{C}$ [36], $6.05 \mathrm{~h}$ in 
tilapia (Oreochromis niloticus) at $30^{\circ} \mathrm{C}$ [35], and $20.6 \mathrm{~h}$ in coho salmon (Oncorhynchus kisutch) at $10{ }^{\circ} \mathrm{C}$ [37]. This prolonged elimination of CFQ in fish species compared to other species has been demonstrated also for other antibacterials in fish. These data indicate there are variations in the elimination rate of CEQ among various species.

The $\mathrm{Vd}_{\mathrm{ss}}$ value is used to indicate the amount of drug in the body under equilibrium conditions. It is the proportionality constant between plasma concentrations of drugs and their total amount in the body [48]. In the present study, the obtained $\mathrm{Vd}_{\mathrm{ss}}$ for CFQ in turkeys was $0.547 \mathrm{~L} / \mathrm{kg}$. this value is close to that recorded for CFQ in ducks $(0.41 \mathrm{~L} / \mathrm{kg}$ [9]), chickens (0.49 L/ kg [38]), laying hens (0.871 L/kg [40]), black swans (0.32 L/kg [11]), and gosling (0.43 L/ kg [39]). These findings demonstrated that the tissue distribution of CFQ in turkeys and other avian species is quite limited after IV administration. In mammals, the $\mathrm{Vd}_{\mathrm{ss}}$ rate of CFQ was also limited after IV administration. The $\mathrm{Vd}_{\mathrm{ss}}$ of CFQ were $0.36 \mathrm{~L} / \mathrm{kg}$ in horses [16], $0.28 \mathrm{~L} / \mathrm{kg} \mathrm{h}$ in cattle [26], $0.37 \mathrm{~L} / \mathrm{kg}$ in premature calves [24], 0.21 and $0.26 \mathrm{~L} / \mathrm{kg}$ in rabbits [31,32], $0.30 \mathrm{~L} / \mathrm{kg}$ beagle dogs [22], $0.28 \mathrm{~L} / \mathrm{kg}$ [28] and $0.36 \mathrm{~L} / \mathrm{kg}$ [27] in sheep. In foals and mares, the $\mathrm{Vd}_{\mathrm{ss}}$ of CFQ after IV administration of $1 \mathrm{mg} / \mathrm{kg}$ was $0.09 \mathrm{~L} / \mathrm{kg}$ [14], and $0.22 \mathrm{~L} / \mathrm{kg}$ [15], respectively. In fish species, the Vd/F (volume of distribution corrected for bioavailability) of CFQ was also limited after intraperitoneal administration of $10 \mathrm{mg} / \mathrm{kg}$ BW. The values of 0.2 and $0.33 \mathrm{~L} / \mathrm{kg}$ were recorded in crucian carp [36] and tilapia [35], respectively. These data of limited distribution indicate the limited penetration of CFQ to the intracellular compartment after IV administration in turkeys, and most other avian, mammals, and fish species. This could be referred to that CFQ is an organic acid with a hydrophilic nature (low lipophilicity), and a small pKa value $(2.51-2.91)[49,50]$. In the present study, the in vitro plasma protein binding of CFQ was limited $(11.5 \%$ ) as has been shown in previous studies (ranged from $5-15 \%$ in most species [40]). The protein binding assay used in the present study did not account for the non-specific drug binding to the centrifugal device which may be a limitation in the present study.

The obtained value of total clearance $\left(\mathrm{CL}_{\mathrm{tot}}\right)$ of $\mathrm{CFQ}$ from turkey bodies in the current study was $0.323 \mathrm{~L} / \mathrm{h} / \mathrm{kg}$. Similar values were reported for CFQ in chickens (0.35 L/h/kg; [38]), duckling (0.32 L/h/ kg; [39]). However, this value was shorter than that of CFQ in gosling $(0.45 \mathrm{~L} / \mathrm{h} / \mathrm{kg}$; [39]), laying hens $(0.62 \mathrm{~L} / \mathrm{h} / \mathrm{kg}$ [40]), and longer than CFQ in ducks (0.22 L/h/ kg; [11]) and black swans (0.13 L/h/ kg [11]). In mammals, the systemic clearance of CFQ was also small after IV administration of $2-4 \mathrm{mg} / \mathrm{kg}$ BW. The $\mathrm{CL}_{\text {tot }}$ of CFQ were $0.158 \mathrm{~L} / \mathrm{h} / \mathrm{kg}$ in horses [16], $0.12 \mathrm{~L} / \mathrm{h} / \mathrm{kg} \mathrm{h}$ in cattle [26], $0.13 \mathrm{~L} / \mathrm{h} / \mathrm{kg}$ in premature calves [24], 0.18 and $0.25 \mathrm{~L} / \mathrm{h} / \mathrm{kg}$ in rabbits [31,32], $0.24 \mathrm{~L} / \mathrm{h} / \mathrm{kg}$ beagle dogs [22], $0.16 \mathrm{~L} / \mathrm{h} / \mathrm{kg}$ in sheep [27]. In foals and mares, the CL tot of CFQ after IV administration of $1 \mathrm{mg} / \mathrm{kg}$ was 0.18 , and $0.13 \mathrm{~L} / \mathrm{h} / \mathrm{kg}$, respectively [15]. All these findings indicate the rapid elimination of CFQ after IV administration in turkeys and most other avian species and mammals. In fish species, the rate of systemic clearance of CFQ was reported after intraperitoneal administration of $10 \mathrm{mg} / \mathrm{kg}$ BW. The values of 0.020 and $0.037 \mathrm{~L} / \mathrm{h} / \mathrm{kg}$ were reported in crucian carp [36] and tilapia [35], respectively, indicating a slower clearance of CFQ in fishes than in avian species and mammals. These data indicate there are variations in the clearance of CEQ among various species.

Following IM administration to turkeys, CFQ was speedily absorbed as the measured absorption half-life $t_{1 / 2 a b}$ was short $(0.25 \mathrm{~h})$. The absorption seems slower in turkeys compared with ducks ( $\mathrm{t}_{1 / 2 \mathrm{ab}}: 0.12 \mathrm{~h}$, [9]), black swans $\left(\mathrm{t}_{1 / 2 \mathrm{ab}}: 0.12 \mathrm{~h},[11]\right)$ and chickens $\left(t_{1 / 2 a b}: 0.07 \mathrm{~h}[38]\right)$. In mammals, the $t_{1 / 2}$ ab values of CFQ were also short after IM injection. 


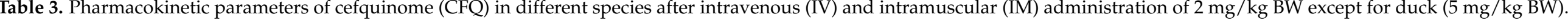

\begin{tabular}{|c|c|c|c|c|c|c|c|c|c|c|}
\hline Species & \multicolumn{2}{|c|}{ Chickens } & \multicolumn{2}{|c|}{ Ducks } & \multicolumn{2}{|c|}{ Black Swans } & \multicolumn{2}{|c|}{ Ducklings } & \multicolumn{2}{|c|}{ Gosling } \\
\hline Dose (mg/kg) & \multicolumn{2}{|c|}{2} & \multicolumn{2}{|c|}{5} & \multicolumn{2}{|c|}{2} & \multicolumn{2}{|c|}{2} & \multicolumn{2}{|c|}{2} \\
\hline Route & IV & IM & IV & IM & IV & IM & IV & IM & IV & IM \\
\hline$\beta(1 / h)$ & $0.54 \pm 0.04$ & $0.53 \pm 0.08$ & $0.44 \pm 0.02$ & $0.39 \pm 0.03$ & $42.09 \pm 0.09$ & $0.43 \pm 0.03$ & - & - & - & - \\
\hline$t_{1 / 2 \alpha}(h)$ & $0.43 \pm 0.19$ & $0.58 \pm 0.27$ & $0.19 \pm 0.05$ & $0.46 \pm 0.30$ & $0.31 \pm 0.03$ & - & 0.019 & 0.343 & 0.446 & 0.483 \\
\hline $\mathrm{t}_{1 / 2 \beta}(\mathrm{h})$ & $1.29 \pm 0.10$ & $1.35 \pm 0.20$ & $1.57 \pm 0.06$ & $1.79 \pm 0.11$ & $1.69 \pm 0.85$ & $1.62 \pm 0.11$ & 0.972 & 1.717 & 1.737 & 1.403 \\
\hline $\begin{array}{l}\mathrm{AUC}_{0-\infty} \\
(\mu \mathrm{g} \cdot \mathrm{h} / \mathrm{mL})\end{array}$ & $5.33 \pm 0.55$ & $5.13 \pm 1.06$ & $25.12 \pm 2.31$ & $23.78 \pm 3.87$ & $16.5 \pm 4.92$ & $12.17 \pm 4.32$ & 6.248 & 4.220 & 4.396 & 5.008 \\
\hline $\mathrm{Vd}_{\mathrm{ss}}(\mathrm{L} / \mathrm{kg})$ & $0.49 \pm 0.05$ & - & $0.41 \pm 0.0$ & - & $0.32 \pm 0.17$ & - & 0.042 & - & 0.432 & - \\
\hline $\mathrm{Cl}_{\text {tot }}(\mathrm{L} / \mathrm{kg} / \mathrm{h})$ & $0.35 \pm 0.04$ & - & $0.22 \pm 0.02$ & & $0.13 \pm 0.04$ & & 0.320 & - & 0.455 & - \\
\hline $\mathrm{t}_{1 / 2 \mathrm{ab}}(\mathrm{h})$ & - & $0.07 \pm 0.02$ & - & $0.12 \pm 0.02$ & - & $0.12 \pm 0.04$ & - & - & - & \\
\hline $\mathrm{C}_{\max }(\mu \mathrm{g} / \mathrm{mL})$ & - & $3.04 \pm 0.71$ & - & $9.38 \pm 1.61$ & - & $5.71 \pm 1.43$ & - & 4.010 & - & 3.400 \\
\hline $\mathrm{T}_{\max }(\mathrm{h})$ & - & $0.25 \pm 0.06$ & - & $0.38 \pm 0.06$ & - & $0.39 \pm 0.19$ & - & 0.163 & - & 0.203 \\
\hline $\mathrm{F}(\%)$ & - & $95.81 \pm 5.81$ & - & $93.28 \pm 13.89$ & - & $74.2 \pm 26.3$ & - & 67.5 & - & 113.9 \\
\hline Reference & \multicolumn{2}{|c|}{$[38]$} & \multicolumn{2}{|c|}{$[9]$} & \multicolumn{2}{|c|}{$[11]$} & \multicolumn{2}{|c|}{ [39] } & \multicolumn{2}{|c|}{ [39] } \\
\hline Species & \multicolumn{2}{|c|}{ Pigs } & \multicolumn{2}{|c|}{ Rabbits } & \multicolumn{2}{|c|}{ Sheep } & \multicolumn{2}{|c|}{ Dogs } & \multicolumn{2}{|c|}{ Calves } \\
\hline Dose (mg/kg) & \multicolumn{2}{|c|}{2} & \multicolumn{2}{|c|}{2} & \multicolumn{2}{|c|}{2} & \multicolumn{2}{|c|}{2} & \multicolumn{2}{|c|}{2} \\
\hline$\beta(1 / h)$ & - & - & $0.76 \pm 0.11$ & $0.69 \pm 0.13$ & - & - & $0.72 \pm 0.11$ & $0.84 \pm 0.13$ & $0.40 \pm 0.11$ & $0.15 \pm 0.02$ \\
\hline$t_{1 / 2 \alpha}(h)$ & $0.30 \pm 0.08$ & $1.33 \pm 0.42$ & - & - & $0.06 \pm 0.04$ & $0.31 \pm 0.05$ & $0.12 \pm 0.05$ & - & - & - \\
\hline$t_{1 / 2 \beta}(h)$ & $2.32 \pm 0.47$ & $4.92 \pm 1.14$ & $0.93 \pm 0.14$ & $1.04 \pm 0.22$ & $0.78 \pm 0.19$ & $1.88 \pm 0.40$ & $0.98 \pm 0.14$ & $0.85 \pm 0.15$ & $1.85 \pm 0.44$ & $4.47 \pm 0.69$ \\
\hline $\begin{array}{c}\mathrm{AUC}_{0-\infty} \\
(\mu \mathrm{g} \cdot \mathrm{h} / \mathrm{mL})\end{array}$ & $18.35 \pm 5.32$ & $17.22 \pm 4.11$ & $11.08 \pm 4.06$ & $10.40 \pm 1.23$ & $5.83 \pm 0.45$ & $5.19 \pm 0.25$ & $8.51 \pm 1.27$ & $8.24 \pm 0.80$ & $15.74 \pm 3.57$ & $22.75 \pm 6.18$ \\
\hline $\mathrm{Vd}_{\mathrm{sS}}(1 / \mathrm{kg})$ & - & - & $0.21 \pm 0.03$ & - & $0.36 \pm 0.06$ & - & $0.30 \pm 0.03$ & - & $0.37 \pm 0.10$ & - \\
\hline $\mathrm{Cl}_{\text {tot }}(\mathrm{L} / \mathrm{kg} / \mathrm{h})$ & $0.12 \pm 0.03$ & - & $0.18 \pm 0.05$ & - & $0.34 \pm 0.03$ & - & $0.24 \pm 0.03$ & - & $0.13 \pm 0.03$ & - \\
\hline $\mathrm{t}_{1 / 2 \mathrm{ab}}(\mathrm{h})$ & - & $0.24 \pm 0.05$ & - & - & - & $0.31 \pm 0.05$ & - & $0.14 \pm 0.05$ & - & - \\
\hline $\mathrm{C}_{\max }(\mu \mathrm{g} / \mathrm{mL})$ & - & $3.36 \pm 0.54$ & - & $8.87 \pm 2.07$ & - & $2.60 \pm 0.14$ & - & $4.83 \pm 0.79$ & - & $4.56 \pm 0.75$ \\
\hline $\mathrm{T}_{\max }(\mathrm{h})$ & - & $0.83 \pm 0.28$ & - & $0.25 \pm 0.12$ & - & $0.50 \pm 0.00$ & - & $0.43 \pm 0.11$ & - & $1.00 \pm 0.00$ \\
\hline $\mathrm{F}(\%)$ & - & $85.13 \pm 9.93$ & - & $95.23 \pm 9.84$ & - & $89.31 \pm 6.06$ & - & $97.8 \pm 9.40$ & - & 141.22 \\
\hline Reference & \multicolumn{2}{|c|}{$[51]$} & \multicolumn{2}{|c|}{$[31]$} & \multicolumn{2}{|c|}{$[27]$} & \multicolumn{2}{|c|}{$[22]$} & \multicolumn{2}{|c|}{$[28]$} \\
\hline
\end{tabular}

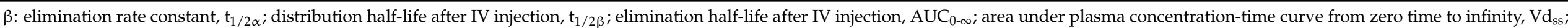

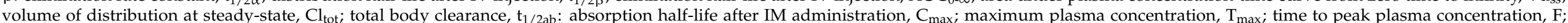

absolute bioavailability. 
The values were $0.28 \mathrm{~h}$ in pigs [52], $0.31 \mathrm{~h}$ in sheep [27], $0.14 \mathrm{~h}$ in beagle dogs [22], $0.16 \mathrm{~h}$ in buffalo calves [53], and $0.45 \mathrm{~h}$ in foals [14]. In fish species, the values were $0.04 \mathrm{~h}$ crucian carp [36] and $0.028 \mathrm{~h}$ in tilapia [35]. These data demonstrated that it takes little time for CFQ to enter the systemic circulation and establish an efficient plasma level in turkeys, other avian species, mammals, and fish species. The calculated $t_{1 / 2 z}$ of CFQ in turkeys after IM administration was $1.71 \mathrm{~h}$, longer than that of IV administration $(1.56 \mathrm{~h})$. The longer $t_{1 / 2 z}$ after extravascular administration than after IV administration may result from precipitation of the drug at the injection site or flip-flop phenomenon, in which the absorption rate of a drug is slower than its rate of elimination $[31,54,55]$. In the present case, the MAT value is expected to be longer than the MRT value after IV administration $\left(\mathrm{MRT}_{\mathrm{IV}}\right)$ as demonstrated before in rabbits [31]. However, the shorter MAT value $(0.374 \mathrm{~h})$ than $\mathrm{MRT}_{\mathrm{IV}}(1.7 \mathrm{~h})$ in the present study does not support the flip-flop phenomenon. After IM injection, some drugs precipitate in increasing amounts at the injection site to provide increasing values of the $t_{1 / 2 z}[54,56]$. Therefore, the precipitation of CFQ at the IM injection site might be the reason for its longer $t_{1 / 2 z}$ compared with the $t_{1 / 2 z}$ after IV administration. The calculated $t_{1 / 2 z}$ of CFQ in turkeys after IM administration is remarkably identical to the value reported for CFQ in ducks (1.79 $\mathrm{h} \mathrm{[9]),} \mathrm{duckling} \mathrm{(1.71} \mathrm{h} \mathrm{[39]),} \mathrm{black} \mathrm{swans}$ (1.62 $\mathrm{h} \mathrm{[11]),} \mathrm{and} \mathrm{longer} \mathrm{than} \mathrm{CFQ} \mathrm{in} \mathrm{chickens} \mathrm{(1.35} \mathrm{h} \mathrm{[38])} \mathrm{and} \mathrm{gosling} \mathrm{(1.40} \mathrm{h} \mathrm{[39]).} \mathrm{How-}$ ever, it is shorter than that obtained for CFQ in laying hens (2.22 h) after IM administration at a dose of $5 \mathrm{mg} / \mathrm{kg}$ BW [40]. In mammals, the $t_{1 / 2 z}$ values of CFQ after IM injection were variable as $4.44 \mathrm{~h}$ in pigs [52], $4.85 \mathrm{~h}$ in goats [47], $0.85 \mathrm{~h}$ in beagle dogs [22], 4.74 $\mathrm{h}$ in premature calves [24], 3.73 h in buffalo calves [53], $0.45 \mathrm{~h}$ in foals [14], 1.04 [31] and $0.72 \mathrm{~h}$ [32] in rabbits. In fish species, the values were longer as $7.39 \mathrm{~h}$ in crucian carp [36] and $5.81 \mathrm{~h}$ in tilapia [35].

The $\mathrm{C}_{\max }$ of $\mathrm{CFQ}$ in turkeys was $2.71 \pm 0.161 \mu \mathrm{g} / \mathrm{mL}$ achieved at $\left(\mathrm{T}_{\max }\right)$ $0.560 \pm 0.0181 \mathrm{~h}$. The obtained $\mathrm{C}_{\max }$ and $\mathrm{T}_{\max }$ value of CFQ $(2 \mathrm{mg} / \mathrm{kg})$ in turkeys was lower than those of CFQ administered at the same dose in duckling $(4.01 \mu \mathrm{g} / \mathrm{mL}$ achieved at $0.163 \mathrm{~h} \mathrm{[39]),} \mathrm{goslings} \mathrm{(} 3.40 \mu \mathrm{g} / \mathrm{mL}$ achieved at $0.203 \mathrm{~h}$ [39]), and chickens ( $3.04 \mu \mathrm{g} / \mathrm{mL}$ achieved at $0.25 \mathrm{~h}$ [38]). In mammals, different values for $\mathrm{C}_{\max }$ and $\mathrm{T}_{\max }$ of CFQ after IM administration of $2 \mathrm{mg} / \mathrm{kg}$ were also demonstrated. The values were $6.43 \pm 0.637 \mu \mathrm{g} / \mathrm{mL}$ achieved at $0.78 \pm 0.771 \mathrm{~h}$ in pigs [52], $2.37 \pm 0.13 \mu \mathrm{g} / \mathrm{mL}$ achieved at $1 \mathrm{~h}$ in goats [47], $4.83 \pm 0.79 \mu \mathrm{g} / \mathrm{mL}$ achieved at $0.43 \pm 0.11 \mathrm{~h}$ in beagle dogs [22], $4.56 \pm 0.75 \mu \mathrm{g} / \mathrm{mL}$ achieved at $1 \mathrm{~h}$ in premature calves [24], $8.78 \pm 2.07 \mu \mathrm{g} / \mathrm{mL}$ achieved at $0.25 \pm 0.12 \mathrm{~h}$ in rabbits [31], and $6.93 \pm 1.72 \mu \mathrm{g} / \mathrm{mL}$ achieved at $0.33 \pm 0.12 \mathrm{~h}$ [32] in rabbits.

The calculated systemic bioavailability of CFQ after the IM administration to turkeys was $95.6 \%$, which is almost identical to that reported for CFQ at a dose of $2 \mathrm{mg} / \mathrm{kg}$ BW in chickens (95.8\% [38]) and ducks at a dose of $5 \mathrm{mg} / \mathrm{kg}$ BW (93.3\% [9]), higher than for CFQ at a dose of $2 \mathrm{mg} / \mathrm{kg}$ BW in duckling (67.5\% [39]), laying hens at a dose of $2 \mathrm{mg} / \mathrm{kg}$ BW (66.8\% [40]), and black swans at a dose of $2 \mathrm{mg} / \mathrm{kg} \mathrm{BW} \mathrm{(74.2 \%} \mathrm{[11]).}$ However, it is lower than for CFQ at a dose of $2 \mathrm{mg} / \mathrm{kg} \mathrm{BW}$ in goslings (113.9\% [39]). In mammals, the bioavailability of CFQ after IM administration was also high as it were $97.8 \%$ in beagle dogs [22], $141.2 \%$ in premature calves [24], $86.3 \%$ in buffalo calves [53], $95.2 \%$ in rabbits [31]. After subcutaneous administration in sheep the value was also high (123.5\% [28]). These data show that CFQ is rapidly and nearly completely absorbed following IM administration to turkeys, other avian species, and mammals. This might be most likely owed to its zwitterionic nature, which allows CFQ to permeate easily into the biological membranes [8]. High bioavailability of CFQ after IM administration into thigh muscles may suggest that the renal portal system and tubular excretion play an insignificant role in the potential first-pass effect often associated with the administration to the caudofemoral portion of the body in birds and reptiles [57]. However, the lack of comparative data on CFQ administration into another part of the body (e.g., breast muscle) prevents any firm conclusions. This may be considered another limitation of the study.

These differences in the disposition profile of CFQ among species are common and attributed to several factors such as inter-species variation in the extent of metabolism, 
differences in the assay methods used, given dose, blood sampling times, age of animals, and/or the health status [58].

The antibacterial activity of CFQ is considered to be time-dependent $[4,26,59]$. This means that the antibacterial efficacy of CFQ is proportionally related to the time that free CFQ concentration in plasma surpasses the MIC (minimum inhibitory concentration) for certain pathogens during the inter-dosing interval $(\% \mathrm{~T}>\mathrm{MIC})$ [60-62]. The field usage of CFQ in turkeys has not been established yet due to the paucity of pharmacokinetic studies and the MICs data of CFQ for turkey's pathogenic bacterial strains. However, MIC values of $\leq 0.1 \mu \mathrm{g} / \mathrm{mL}$ typically reported for pathogens isolated from different species suggest the high clinical efficacy of this antibiotic $[63,64]$. In literature, data revealed that CFQ is effective against numerous bacteria isolated from other poultry species that can induce health problems in turkeys. For example, E. coli O78 and Salmonella strain C79-13 from chickens were very susceptible to low serum concentrations of CFQ with a MIC of 0.063 and $0.25 \mu \mathrm{g} / \mathrm{mL}$, respectively [65]. Also, Pasturella multocida and Ornithobacterium rhinotracheale isolated from avian species like turkeys, ducks, geese, chicken, and pheasants were very sensitive to CFQ $[66,67]$. Further, Riemerella anatipestifer isolated strains from ducks and geese were susceptible to CFQ with $\mathrm{MIC}_{50}$ of $0.031 \mu \mathrm{g} / \mathrm{mL}$ and $\mathrm{MIC}_{90}$ levels of $0.5 \mu \mathrm{g} / \mathrm{mL}$ [68]. Additionally, in black swans, the $\mathrm{MIC}_{50}$ and MIC 90 values for CFQ against 49 E. coli strains were 0.063 and $0.5 \mu \mathrm{g} / \mathrm{mL}$, respectively [11]. In the current study, the time that plasma level of CFQ maintained above $0.1 \mu \mathrm{g} / \mathrm{mL}$ after the IM administration of $2 \mathrm{mg} / \mathrm{kg}$ BW was $8 \mathrm{~h}$. In general, to attain an adequate therapeutic efficiency of numerous cephalosporins, the time in which free drug concentration in plasma surpasses the MIC should be higher than $40 \%$ of the inter-dosing interval [48,69-72]. Based on these data and the findings of the present study, a twice-daily dosage of $2 \mathrm{mg} / \mathrm{kg}$ BW of CFQ given intramuscularly to turkeys at the age of $17-20$ weeks and $7-8.5 \mathrm{~kg}$ of BW would be efficient against several susceptible bacterial strains. However, some recent reports on antimicrobial pharmacokinetics in turkeys revealed that elimination processes differ depending on the age of the birds. For example, Poźniak et al. found that the rapid growth in turkeys significantly affected amoxicillin pharmacokinetics wherein younger turkeys $(2 \mathrm{~kg})$, the $\mathrm{t}_{1 / 2 \mathrm{z}}$ was approximately two-fold shorter $(0.67 \mathrm{~h})$ than at $12 \mathrm{~kg}(1.28 \mathrm{~h})$ [73]. Also, Świtała et al. reported in turkeys that, between the 5 th and 15 th week of age, $\mathrm{CL}_{\text {tot }}$ of metronidazole declined from 3.6 to $1.2 \mathrm{~mL} / \mathrm{min} / \mathrm{kg}$ causing a twofold rise in the MRT and $\mathrm{t}_{1 / 2 z}$ [74]. These differences are probably due to the changes that occurred in heart rate, cardiac output, enzymatic functions, and or alteration in clearing organ perfusion [74]. Therefore, the lack of the perspective of age-dependent change in cefquinome pharmacokinetics is a limitation of the present study.

\section{Conclusions}

After IM administration of CFQ, there were no local reactions and adverse effects. Further, CFQ revealed rapid absorption and high bioavailability. Concentrations exceeding MIC values for most of the poultry pathogens indicate that the repeated (twice-daily) IM administration of CFQ at $2 \mathrm{mg} / \mathrm{kg}$ BW might be highly efficacious against susceptible bacterial pathogens in turkeys. However, additional studies should be carried out to set a multiple dosage regimen, assess the clinical efficacy of CFQ and its residues in the edible tissues of this species.

Supplementary Materials: The following are available online at https:/ /www.mdpi.com/article/10 .3390/pharmaceutics13111804/s1, Figure S1: Representative High-performance liquid chromatography chromatograms of cefquinome (CFQ) from standard and spiked turkeys' plasma (A: standard, B: spiked plasma), Table S1: Cefquinome (CFQ) concentration in individual turkey at different sampling time after intravenous (IV) and intramuscular (IM) administration of $2 \mathrm{mg} / \mathrm{kg}$ body weight, Table S2: Pharmacokinetic parameters of cefquinome (CFQ) in individual turkey after intravenous (IV) and intramuscular (IM) administration of $2 \mathrm{mg} / \mathrm{kg}$ body weight. 
Author Contributions: Conceptualization: M.E., M.A.; Methodology: M.E., A.S., A.A. (Amira Abugomaa), M.A.; Software and validation, M.E., A.S., A.A. (Amira Abugomaa), A.A. (Adel Alkhedaide); Analysis, M.E., M.M.S., A.A. (Amira Abugomaa); Resources, M.E., M.A.; WritingOriginal Draft Preparation: M.E., A.S., M.A.; Writing—Review \& Editing: M.E., M.A., M.M.S., A.A. (Adel Alkhedaide); Funding Acquisition, M.E., M.M.S., A.A. (Adel Alkhedaide), M.A. All authors have read and agreed to the published version of the manuscript.

Funding: This study was supported by the Taif University Researchers Supporting Project (TURSP2020/104), Taif University, Taif, Saudi Arabia.

Institutional Review Board Statement: All experimental procedures of the current study were performed following the guidelines set by the local Ethical Committee of Faculty of Veterinary Medicine, Benha University, Egypt (Ethical Approval Number: BUFVTM 02-07-21).

Informed Consent Statement: Not applicable.

Data Availability Statement: All relevant data are included in the manuscript.

Acknowledgments: We appreciate and thank Taif University for the financial support for Taif University Researchers Supporting Project (TURSP-2020/104), Taif University, Taif, Saudi Arabia.

Conflicts of Interest: The author declared no conflict of interest.

\section{References}

1. Elbadawy, M.; Aboubakr, M.; Abugomaa, A. Pharmacokinetics of Tylvalosin in Broiler Turkeys (Meleagris gallopavo) After Single Intravenous and Oral Administration. Front. Vet. Sci. 2019, 6, 355. [CrossRef]

2. Hornish, R.; Katarski, R.E.H.A.S.F. Cephalosporins in Veterinary Medicine-Ceftiofur Use in Food Animals. Curr. Top. Med. Chem. 2002, 2, 717-731. [CrossRef]

3. Becker, M.; Zittlau, E.; Petz, M. Residue analysis of 15 penicillins and cephalosporins in bovine muscle, kidney and milk by liquid chromatography-tandem mass spectrometry. Anal. Chim. Acta 2004, 520, 19-32. [CrossRef]

4. Thomas, E.; Thomas, V.; Wilhelm, C. Antibacterial activity of cefquinome against equine bacterial pathogens. Vet. Microbiol. 2006, 115, 140-147. [CrossRef]

5. Broens, E.M.; Van Geijlswijk, I.M. Prudent Use of Antimicrobials in Exotic Animal Medicine. Vet. Clin. N. Am. Exot. Anim. Pr. 2018, 21, 341-353. [CrossRef]

6. Chin, N.-X.; Gu, J.-W.; Fang, W.; Neu, H.C. In vitro activity of cefquinome, a new cephalosporin, compared with other cephalosporin antibiotics. Diagn. Microbiol. Infect. Dis. 1992, 15, 331-337. [CrossRef]

7. Shan, Q.; Wang, J. Activity of cefquinome against extended-spectrum $\beta$-lactamase-producing Klebsiella pneumoniae in neutropenic mouse thigh model. J. Vet. Pharmacol. Ther. 2016, 40, 392-397. [CrossRef]

8. Guérin-Faublée, V.; Carret, G.; Houffschmitt, P. In vitro activity of 10 antimicrobial agents against bacteria isolated from cows with clinical mastitis. Vet. Rec. 2003, 152, 466-471. [CrossRef]

9. Yuan, L.; Sun, J.; Wang, R.; Sun, L.; Zhu, L.; Luo, X.; Fang, B.; Liu, Y. Pharmacokinetics and bioavailability of cefquinome in healthy ducks. Am. J. Vet. Res. 2011, 72, 122-126. [CrossRef] [PubMed]

10. Limbert, M.; Isert, D.; Klesel, N.; Markus, A.; Seeger, K.; Seibert, G.; Schrinner, E. Antibacterial activities in vitro and in vivo and pharmacokinetics of cefquinome (HR 111V), a new broad-spectrum cephalosporin. Antimicrob. Agents Chemother. 1991, 35, 14-19. [CrossRef] [PubMed]

11. Zhao, D.-H.; Wang, X.-F.; Wang, Q.; Li, L.-D. Pharmacokinetics, bioavailability and dose assessment of Cefquinome against Escherichia coli in black swans (Cygnus atratus). BMC Vet. Res. 2017, 13, 226. [CrossRef] [PubMed]

12. Mi, K.; Li, M.; Sun, L.; Hou, Y.; Zhou, K.; Hao, H.; Pan, Y.; Liu, Z.; Xie, C.; Huang, L. Determination of Susceptibility Breakpoint for Cefquinome against Streptococcus suis in Pigs. Antibiotics 2021, 10, 958. [CrossRef] [PubMed]

13. Rossi, R.S.; Amarante, A.F.; Guerra, S.T.; Latosinski, G.S.; Rossi, B.F.; Rall, V.L.M.; Pantoja, J.C.D.F. Efficacy of cefquinome and a combination of cloxacillin and ampicillin for treatment of dairy cows with Streptococcus agalactiae subclinical mastitis. PLoS ONE 2019, 14, e0216091. [CrossRef] [PubMed]

14. Lee, D.H.; Birhanu, B.T.; Lee, E.B.; Lee, S.J.; Boby, N.; Park, Y.S.; Park, S.C. Pharmacokinetic and pharmacodynamic integration for optimal dosage of cefquinome against Streptococcus equi subsp. equi in foals. Vet. Res. 2020, 51, 131. [CrossRef]

15. Smiet, E.; Haritova, A.; Heil, B.A.; Fink-Gremmels, J.; Wijnberg, I.D. Comparing the pharmacokinetics of a fourth generation cephalosporin in three different age groups of New Forest ponies. Equine Vet. J. 2012, 44, 52-56. [CrossRef] [PubMed]

16. Uney, K.; Altan, F.; Altan, S.; Erol, H.; Arican, M.; Elmas, M. Plasma and synovial fluid pharmacokinetics of cefquinome following the administration of multiple doses in horses. J. Vet. Pharmacol. Ther. 2016, 40, 239-247. [CrossRef]

17. Zhao, D.H.; Zhang, C.Y.; Zhang, Z.; Liu, Z.C.; Liu, B.T.; Yu, J.J.; Guo, J.P.; Deng, H.; Liu, Y.H. Population pharmacokinetics of cefquinome in pigs. J. Vet. Pharmacol. Ther. 2013, 36, 313-319. [CrossRef]

18. Zhang, B.; Lu, X.; Gu, X.; Li, X.; Gu, M.; Zhang, N.; Shen, X.; Ding, H. Pharmacokinetics and ex vivo pharmacodynamics of cefquinome in porcine serum and tissue cage fluids. Vet. J. 2014, 199, 399-405. [CrossRef] 
19. Zhang, L.; Wu, X.; Huang, Z.; Zhang, N.; Wu, Y.; Cai, Q.; Shen, X.; Ding, H. Pharmacokinetic/pharmacodynamic assessment of cefquinome against Actinobacillus Pleuropneumoniae in a piglet tissue cage infection model. Vet. Microbiol. 2018, 219, 100-106. [CrossRef] [PubMed]

20. Zhang, L.; Wu, X.; Huang, Z.; Kang, Z.; Chen, Y.; Shen, X.; Cai, Q.; Ding, H. Pharmacokinetic/pharmacodynamic integration of cefquinome against Pasteurella Multocida in a piglet tissue cage model. J. Vet. Pharmacol. Ther. 2018, 42, 60-66. [CrossRef]

21. Zhang, B.; Gu, X.; Li, X.; Gu, M.; Zhang, N.; Shen, X.; Li, Y.; Ding, H. Pharmacokinetics and ex-vivo pharmacodynamics of cefquinome against Klebsiella pneumonia in healthy dogs. J. Vet. Pharmacol. Ther. 2014, 37, 367-373. [CrossRef] [PubMed]

22. Zhou, Y.-F.; Zhao, D.H.; Yu, Y.; Yang, X.; Shi, W.; Peng, Y.B.; Liu, Y.H. Pharmacokinetics, bioavailability and PK/PD relationship of cefquinome for Escherichia coli in Beagle dogs. J. Vet. Pharmacol. Ther. 2015, 38, 543-548. [CrossRef]

23. Venkatachalam, D.; Dumka, V.K.; Ranjan, B. Pharmacokinetics of a single intramuscular injection of cefquinome in buffalo calves. J. Vet. Pharmacol. Ther. 2017, 41, 155-158. [CrossRef] [PubMed]

24. Corum, O.; Yildiz, R.; Ider, M.; Altan, F.; Ok, M.; Uney, K. Pharmacokinetics and bioavailability of cefquinome and ceftriaxone in premature calves. J. Vet. Pharmacol. Ther. 2019, 42, 632-639. [CrossRef]

25. Shan, Q.; Yang, F.; Wang, J.; Ding, H.; He, L.; Zeng, Z. Pharmacokinetic/pharmacodynamic relationship of cefquinome against Pasteurella multocida in a tissue-cage model in yellow cattle. J. Vet. Pharmacol. Ther. 2014, 37, 178-185. [CrossRef] [PubMed]

26. Ahmad, I.; Hao, H.; Huang, L.; Sanders, P.; Wang, X.; Chen, D.; Tao, Y.; Xie, S.; Xiuhua, K.; Li, J.; et al. Integration of PK/PD for dose optimization of Cefquinome against Staphylococcus aureus causing septicemia in cattle. Front. Microbiol. 2015, 6, 588. [CrossRef]

27. Uney, K.; Altan, F.; Elmas, M. Development and Validation of a High-Performance Liquid Chromatography Method for Determination of Cefquinome Concentrations in Sheep Plasma and Its Application to Pharmacokinetic Studies. Antimicrob. Agents Chemother. 2010, 55, 854-859. [CrossRef] [PubMed]

28. Corum, O.; Corum, D.D.; Er, A.; Uney, K. Pharmacokinetics of cefquinome after single and repeated subcutaneous administrations in sheep. J. Vet. Pharmacol. Ther. 2019, 42, 647-653. [CrossRef] [PubMed]

29. El Badawy, S.A.; Amer, A.M.M.; Kamel, G.M.; Eldeib, K.M.; Constable, P.D. Pharmacokinetics and pharmacodynamics of intramammary cefquinome in lactating goats with and without experimentally induced Staphylococcus aureus mastitis. J. Vet. Pharmacol. Ther. 2019, 42, 452-460. [CrossRef]

30. Litterio, N.J.; Lorenzutti, A.M.; Zarazaga, M.D.P.; Himelfarb, M.A.; Andrés-Larrea, M.I.S.; Serrano-Rodríguez, J.M. Comparative pharmacokinetics and pharmacokinetic/pharmacodynamic analysis by nonlinear mixed-effects modeling of cefquinome in nonpregnant, pregnant, and lactating goats after intravenous and intramuscular administration. J. Vet. Pharmacol. Ther. 2021, 44, 68-78. [CrossRef]

31. Hwang, Y.H.; Song, I.B.; Lee, H.K.; Kim, T.W.; Kim, M.S.; Lim, J.H.; Park, B.K.; Yun, H.I. Pharmacokinetics and bioavailability of cefquinome in rabbits following intravenous and intramuscular administration. J. Vet. Pharmacol. Ther. 2011, 34, 618-620. [CrossRef]

32. ElAzab, S.T.; Schrunk, D.E.; Griffith, R.W.; Ensley, S.M.; Dell'Anna, G.; Mullin, K.; Elsayed, M.G.; Amer, M.S.; El-Nabtity, S.M.; Hsu, W.H. Pharmacokinetics of cefquinome in healthy and Pasteurella multocida-infected rabbits. J. Vet. Pharmacol. Ther. 2018, 41, 374-377. [CrossRef]

33. Zhang, L.; Yao, L.; Kang, Z.; Huang, Z.; Gu, X.; Shen, X.; Ding, H. Microdialysis Determination of Cefquinome Pharmacokinetics in Murine Thigh From Healthy, Neutropenic, and Actinobacillus pleuropneumoniae-Infected Mice. Front. Pharmacol. 2019, 10, 249. [CrossRef]

34. Zhang, L.; Zhou, Z.; Gu, X.; Huang, S.; Shen, X.; Ding, H. Murine Thigh Microdialysis to Evaluate the Pharmacokinetic/Pharmacodynamic Integration of Cefquinome Against Actinobacillus pleuropneumoniae. Front. Vet. Sci. 2020, 7, 448. [CrossRef]

35. Shan, Q.; Zhu, X.; Liu, S.; Bai, Y.; Ma, L.; Yin, Y.; Zheng, G. Pharmacokinetics of cefquinome in tilapia (Oreochromis niloticus) after a single intramuscular or intraperitoneal administration. J. Vet. Pharmacol. Ther. 2015, 38, 601-605. [CrossRef]

36. Shan, Q.; Wang, J.; Yang, F.; Ma, L.; Yin, Y.; Liu, S.; Li, L.; Zheng, G. Pharmacokinetics of cefquinome in crucian carp (Carassius auratus gibelio) after oral, intramuscular, intraperitoneal, and bath administration. J. Vet. Pharmacol. Ther. 2018, 41, 734-738. [CrossRef]

37. Martín, B.N.S.; Bataglia, J.; Hernandez, P.; Quiroz, A.; Cañon, H. Absorption and Excretion of Cefquinome in Coho Salmon (Oncorhynchus kisutch) in Freshwater at $10^{\circ}$ C. J. Vet. Med. Ser. A 1998, 45, 615-623. [CrossRef]

38. Xie, W.; Zhang, X.; Wang, T.; Du, S. Pharmacokinetic analysis of cefquinome in healthy chickens. Br. Poult. Sci. 2013, 54, 81-86. [CrossRef]

39. Cheng, P.; Feng, T.; Zhang, Y.; Li, X.; Tian, L.; Wu, J.; Cheng, F.; Zeng, Y.; Chen, H.; He, X.; et al. Comparative pharmacokinetics of intravenous and intramuscular cefquinome sulfate administration in ducklings and goslings. Am. J. Vet. Res. 2020, 81, 837-877. [CrossRef]

40. Saleem, R. Pharmacokinetics of Cefquinome in Layer Birds Following Intramuscular and Intravenous Administration. Pak. Vet. J. 2019, 39, 493-498. [CrossRef]

41. Lashev, L.D.; Haritova, A. Allometric analysis of antibacterial drugs in avian species. Bulg. J. Vet. Med. 2012, 15, $93-109$. 
42. Poźniak, B.; Tikhomirov, M.; Motykiewicz-Pers, K.; Bobrek, K.; Świtała, M. The influence of age and body weight gain on enrofloxacin pharmacokinetics in turkeys-Allometric approach to dose optimization. J. Vet. Pharmacol. Ther. 2019, 43, 67-78. [CrossRef]

43. Sibbald, B.; Roberts, C. Understanding controlled trials: Crossover trials. BMJ 1998, 316, 1719-1720. [CrossRef]

44. Craig, W.; Suh, B. Protein binding and the antimicrobial effects: Methods for determination of protein binding. In Antibiotics in Laboratory Medicine, 3rd ed.; Lorian, V., Ed.; Williams and Wilkins: Baltimore, MD, USA, 1991; pp. 367-402.

45. Gibaldi, M.; Perrier, D. Noncompartmental analysis based on statistical moment theory. In Pharmacokinetics, 2nd ed.; Gibaldi, M., Perrier, D., Eds.; Informa Healthcare: New York, NY, USA, 1982; pp. 409-417.

46. Urso, R.; Blardi, P.; Giorgi, G. A short introduction to pharmacokinetics. Eur. Rev. Med. Pharmacol. Sci. 2003, 6, 33-44.

47. Tekeli, I.O.; Turk, E.; Corum, D.D.; Corum, O.; Kirgiz, F.C.; Sakin, F.; Uney, K. Effect of ketoprofen co-administration on pharmacokinetics of cefquinome following repeated administration in goats. J. Vet. Pharmacol. Ther. 2020, 43, 440-447. [CrossRef]

48. Toutain, P.L.; Lees, P. Integration and modelling of pharmacokinetic and pharmacodynamic data to optimize dosage regimens in veterinary medicine. J. Vet. Pharmacol. Ther. 2004, 27, 467-477. [CrossRef]

49. Committee for Veterinary Medicinal Products (CVMP). Cefquinome Summary Report; EMEA/MRL/005/95; European Medicines Agency: London, UK, 1995; Available online: http:/ / www.ema.europa.eu/docs/en_GB/document_library/Maximum_Residue_ Limits_-_Report/2009/11/WC500011877.pdf (accessed on 27 July 2021).

50. Li, X.B.; Wu, W.X.; Su, D.; Wang, Z.J.; Jiang, H.Y.; Shen, J.Z. Pharmacokinetics and bioavailability of cefquinome in healthy piglets. J. Vet. Pharmacol. Ther. 2008, 31, 523-527. [CrossRef]

51. LU, G.F.; Yang, H.F.; LI, Y.J.; Jiang, C.M. Pharmacokinetics of cefquinome sulfate suspension in pigs. J. Yangzhou Univ. 2007, 28, 18-20. (In Chinese)

52. Zhang, S.; Dai, W.; Lu, Z.; Lei, Z.; Yang, B.; He, B.; Zhou, H.; Cao, J. Preparation and evaluation of cefquinome-loaded gelatin microspheres and the pharmacokinetics in pigs. J. Vet. Pharmacol. Ther. 2017, 41, 117-124. [CrossRef]

53. Venkatachalam, D.; Dumka, V.K. Pharmacokinetic profile of cefquinome after oral subchronic flubendiamide exposure and in vitro plasma protein binding in buffalo calves. Environ. Toxicol. Pharmacol. 2015, 39, 321-326. [CrossRef]

54. Toutain, P.-L.; Bousquet-Melou, A. Plasma terminal half-life. J. Vet. Pharmacol. Ther. 2004, 27, 427-439. [CrossRef] [PubMed]

55. Yáñez, J.A.; Remsberg, C.M.; Sayre, C.L.; Forrest, M.L.; Davies, N.M. Flip-flop pharmacokinetics-delivering a reversal of disposition: Challenges and opportunities during drug development. Ther. Deliv. 2011, 2, 643-672. [CrossRef]

56. Mckellar, Q.A.; Bogan, J.A.; von Fellenberg, R.-L.; Ludwig, B.; Cawley, G.D. Pharmacokinetic, biochemical and tolerance studies on carprofen in the horse. Equine Vet. J. 1991, 23, 280-284. [CrossRef]

57. Holz, P.; Barker, I.K.; Burger, J.P.; Crawshaw, G.J.; Conlon, P.D. The effect of the renal portal system on pharmacokinetic parameters in the red-eared slider (Trachemys scripta elegans). J. Zoo Wildl. Med. 1997, 28, 386-393.

58. Toutain, P.-L.; Ferran, A.A.; Bousquet-Melou, A. Species Differences in Pharmacokinetics and Pharmacodynamics. Comp. Vet. Pharmacol. 2010, 199, 19-48. [CrossRef]

59. Zhang, B.; Gu, X.; Li, Y.; Li, X.; Gu, M.; Zhang, N.; Shen, X.; Ding, H. In vivo evaluation of mutant selection window of cefquinome against Escherichia coliin piglet tissue-cage model. BMC Vet. Res. 2014, 10, 448. [CrossRef]

60. Wang, J.; Shan, Q.; Ding, H.; Liang, C.; Zeng, Z. Pharmacodynamics of Cefquinome in a Neutropenic Mouse Thigh Model of Staphylococcus aureus Infection. Antimicrob. Agents Chemother. 2014, 58, 3008-3012. [CrossRef]

61. McKellar, Q.A.; Sanchez Bruni, S.F.; Jones, D.G. Pharmacokinetic/pharmacodynamic relationships of antimicrobial drugs used in veterinary medicine. J. Vet. Pharmacol. Ther. 2004, 27, 503-514. [CrossRef]

62. Barbour, A.; Scaglione, F.; Derendorf, H. Class-dependent relevance of tissue distribution in the interpretation of anti-infective pharmacokinetic/pharmacodynamic indices. Int. J. Antimicrob. Agents 2010, 35, 431-438. [CrossRef]

63. Orden, J.A.; Ruiz-Santa-Quiteria, J.A.; García, S.; Cid, D.; de la Fuente, R. In Vitro Activities of Cephalosporins and Quinolones against Escherichia coli Strains Isolated from Diarrheic Dairy Calves. Antimicrob. Agents Chemother. 1999, 43, 510-513. [CrossRef]

64. Wisselink, H.J.; Veldman, K.T.; Eede, C.V.D.; Salmon, S.A.; Mevius, D.J. Quantitative susceptibility of Streptococcus suis strains isolated from diseased pigs in seven European countries to antimicrobial agents licenced in veterinary medicine. Vet. Microbiol. 2006, 113, 73-82. [CrossRef]

65. Aarestrup, F.M.; Hasman, H.; Veldman, K.; Mevius, D. Evaluation of Eight Different Cephalosporins for Detection of Cephalosporin Resistance in Salmonella enterica and Escherichia coli. Microb. Drug Resist. 2010, 16, 253-261. [CrossRef] [PubMed]

66. Ak, S.; Keles, O.; Bakirel, T. In vitro antibacterial activities of tilmicosin and cefquinome alone or in combination against certain poultry pathogens. Turk. J. Vet. Anim. Sci. 2001, 25, 577-580.

67. Sellyei, B.; Varga, Z.; Szentesi-Samu, K.; Kaszanyitzky, É.; Magyar, T. Antimicrobial susceptibility of Pasteurella multocida isolated from swine and poultry. Acta Vet. Hung. 2009, 57, 357-367. [CrossRef]

68. Li, Y.; Zhang, Y.; Ding, H.; Mei, X.; Liu, W.; Zeng, J.; Zeng, Z. In vitro susceptibility of four antimicrobials against Riemerella anatipestifer isolates: A comparison of minimum inhibitory concentrations and mutant prevention concentrations for ceftiofur, cefquinome, florfenicol, and tilmicosin. BMC Vet. Res. 2016, 12, 250. [CrossRef]

69. Shan, Q.; Liang, C.; Wang, J.; Li, J.; Zeng, Z. In VivoActivity of Cefquinome against Escherichia coli in the Thighs of Neutropenic Mice. Antimicrob. Agents Chemother. 2014, 58, 5943-5946. [CrossRef]

70. Craig, W.A. Interrelationship between pharmacokinetics and pharmacodynamics in determining dosage regimens for broadspectrum cephalosporins. Diagn. Microbiol. Infect. Dis. 1995, 22, 89-96. [CrossRef] 
71. Craig, W.A. State-of-the-Art Clinical Article: Pharmacokinetic/Pharmacodynamic Parameters: Rationale for Antibacterial Dosing of Mice and Men. Clin. Infect. Dis. 1998, 26, 1-10. [CrossRef]

72. Nie, H.; Feng, X.; Peng, J.; Liang, L.; Lu, C.; Tiwari, R.V.; Tang, S.; He, J. Comparative pharmacokinetics of ceftiofur hydrochloride and ceftiofur sodium after administration to water buffalo (Bubalus bubalis). Am. J. Vet. Res. 2016, 77, 646-652. [CrossRef] [PubMed]

73. Poźniak, B.; Pasławska, U.; Motykiewicz-Pers, K.; Switala, M. The influence of growth and E. coli endotoxaemia on amoxicillin pharmacokinetics in turkeys. Br. Poult. Sci. 2017, 58, 462-468. [CrossRef] [PubMed]

74. Świtała, M.; Poźniak, B.; Pasławska, U.; Grabowski, T.; Motykiewicz-Pers, K.; Bobrek, K. Metronidazole pharmacokinetics during rapid growth in turkeys-relation to changes in haemodynamics and drug metabolism. J. Vet. Pharmacol. Ther. 2016, 39, 373-380. [CrossRef] 